\title{
ANATOMIC STUDY OF THE DORSAL ARTERIAL SYSTEM OF THE HAND
}

\author{
Marcelo Rosa de Rezende, Rames Mattar Júnior, Álvaro Baik Cho, Oswaldo \\ Hideo Hasegawa and Samuel Ribak
}

REZENDE MR de et al. - Anatomic study of the dorsal arterial system of the hand. Rev. Hosp. Clín. Fac. Med. S. Paulo 59(2):71-76, 2004.

Historically, the dorsal arterial system of the hand received less attention than the palmar system. The studies concerning dorsal arterial anatomy present some controversies regarding the origin and presence of the dorsal metacarpal artery branches. Knowledge of the anatomy of dorsal metacarpal arteries is especially applied in the surgical planning for flaps taken from the dorsum of the hand. The purpose of this study is to analyze the arterial anatomy of the dorsum of the hand, compare our observations with those of previous studies from the literature, and therefore to define parameters for surgical planning for flaps supplied by the dorsal metacarpal arteries.

METHOD: Twenty-six dissections were performed at the dorsum of the right hand of 26 cadavers by making a distalbased U-shaped incision. After catheterization of the radial artery at the wrist level, a plastic dye solution with low viscosity and quick solidification was injected to allow adequate exposure of even small vessels. The radial artery and its branches, the dorsal arterial arch, the dorsal metacarpal arteries, the distal and proximal communicating branches of the palmar system, and the distal cutaneous branches were carefully dissected and identified.

RESULTS: The distal cutaneous branches originating from the dorsal metacarpal arteries were observed in all cases; these were located an average of $1.2 \mathrm{~cm}$ proximal from the metacarpophalangeal joint. The first dorsal metacarpal artery presented in 3 different patterns regarding its course: fascial, subfascial, and mixed. The branching pattern of the radial artery at the first intermetacarpal space was its division into 3 branches. We observed the presence of the dorsal arterial arch arising from the radial artery in $100 \%$ of the cases. The distance between the dorsal arterial arch and the branching point of the radial artery was an average of $2 \mathrm{~cm}$. The first and second dorsal metacarpal arteries were visualized in all cases. The third and fourth dorsal metacarpal arteries were visualized in $96.2 \%$ and $92.3 \%$ of cases, respectively. There was proximal and distal communication between the dorsal arterial arch and the palmar system through the communicating branches contributing to the dorsal metacarpal artery formation.

CONCLUSION: At the dorsum of the hand there is a rich arterial net that anastomoses with the palmar arterial system. This anatomical characteristic allows the utilization of the dorsal aspect of the hand as potential donor site for cutaneous flaps.

KEY WORDS: Arterial system. Dorsal. Hand. Anatomy. Fasciocutaneous flaps.

Many kinds of flaps have been proposed for covering the dorsal aspect of the hand ${ }^{1-3}$. Foucher \& Braun's article (1979) was the first to describe the flap supplied by the first dorsal metacarpal artery (1DMA $)^{4}$. In reviewing the literature regarding the anatomy of the dorsal arterial system of the hand, we noticed some controversy about the fre- quency of the dorsal metacarpal arteries (DMAs) ${ }^{4-8}$, the location of the distal cutaneous branches $5,9-12$, and the

From the Institute of Orthopedics and Traumatology, Hospital das Clínicas, Faculty of Medicine, University of São Paulo - São Paulo/SP, Brazil.

Received for publication on September 16, 2003. amount of contribution of the dorsal and palmar arterial system to the formation of the DMAs ${ }^{13-15}$. Since that information is of extreme importance for the operative procedure to raise the flaps based on the DMAs, we found it to be useful to study the anatomy of the dorsal arterial system, focusing on the controversial aspects of the literature. 


\section{METHOD}

For the study of dorsal arterial system of the hand, 26 dissections in 26 cadavers were performed in the Obit Verification Service of our University. All specimens were male, with a mean age of 47.2 years (range 29 to 71 years). The cadavers were chosen randomly, and no female were used due to legal restrictions.

The radial artery was identified following a $3 \mathrm{~cm}$ longitudinal incision made between the flexor carpi radialis and the abductor pollicis longus tendons in the volar and radial aspect of the wrist. It was dissected and divided $1 \mathrm{~cm}$ proximally to the radius styloid process. A catheter was introduced $2 \mathrm{~cm}$ into the distal stump of the vessel and fixed to preclude dye solution leakage. The radial artery and its branches were washed with $20 \mathrm{~mL}$ of saline solution followed by manual injection of $6 \mathrm{~mL}$ of dye solution - a mixture of lead oxide, vinyl, latex, and acetone-in pulsing manner. This blue solution had low density and proved to be quite effective in depicting even very small vessels. This technique is a modification of the technique described by other authors in previous studies ${ }^{16}$. Before the beginning of the dissection, there was an interval of 10 minutes for solidification of the dye solution. All the dissections were performed by the same author under loupes magnification (3.5X).

The dissection was made with a dorsal U-shaped incision, starting at the transition of the dorsal and palmar skin, at the level of fifth metacarpophalangeal (MCP) joint. Then, the incision turned radially, $1 \mathrm{~cm}$ proximal to the ulnar styloid and continued transversally across the wrist, turning distally again at the level of radius styloid, ending at the level of the second MCP joint. The distal-based flap was elevated between the subcutaneous tissue and the fascia. The dorsal retinaculum of the second, third, and fourth extensor compartments was opened longitudinally. The extensor pollicis longus, extensor digitorum communis, and extensor indicis proprius tendons were divided proximally and retracted distally. The second compartment tendons were separated from their insertions and retracted proximally. At this point, the radial artery and its branches, the dorsal arterial arch (DAA), the DMAs, the distal and proximal communicating branches of the palmar system, and the distal cutaneous branches were carefully dissected and identified. The distance between the emergence of the DAA and the branching point of the radial artery and the distance of the distal cutaneous branches from the MCP joints were measured.

\section{RESULTS}

Just distal to the tendinous junctures between the extensor tendons, the second, third, and the fourth dorsal metacarpal arteries (DMAs) gave off small branches, the distal cutaneous branches, that perforated the fascia and the subcutaneous plane to supply the dorsal skin of the hand. (Fig. 1). They were identified all DMAs, in $100 \%$ of the cases. The distance between the emergence point of these branches (from the DMAs) and the MCP joint of the adjacent ulnar digit averaged $1.2 \mathrm{~cm}$.

The course of the first DMA was fascial in $14(53.8 \%)$ cases and subfascial in 2 (7.7\%). It was duplicated in 10 cases $(38.4 \%)$, with one fascial and another subfascial branch in $8(30.8 \%)$ and a double fascial branch in $2(7.7 \%)$. The first DMA was found in the first intermetacarpal space in all specimens, and it arose from the radial artery in all except 1 case, in which it arose from a branch of the radial artery that ran to the dorso-radial aspect of the thumb (Fig. 2).

The radial artery divided into 3 branches between the base of first and second metacarpals in $22(84.6 \%)$ specimens: the princeps pollicis artery, the first DMA, and the branch to the deep palmar arterial arch (Fig. 3). In 4 (15.3\%) specimens, it divided into 4

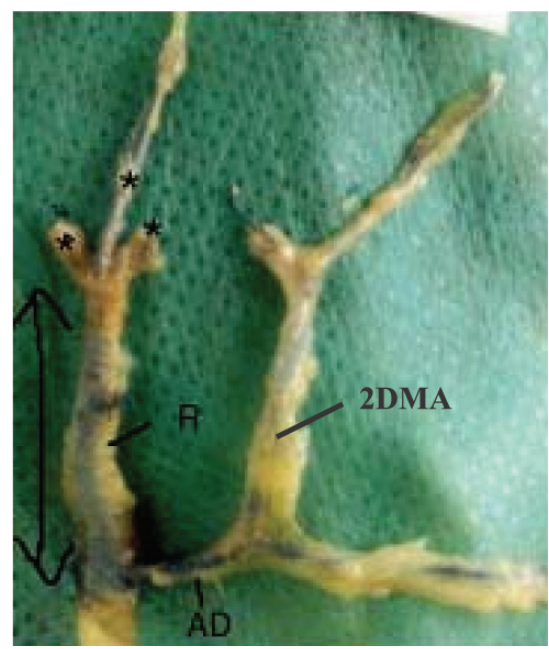

Figure 1 - The most common pattern of ramification of the radial artery at the level of anatomic snuffbox.. R: radial artery; AD: dorsal arterial arch; $1^{*}$ : princeps pollicis artery; $2 *$ : first dorsal metacarpal artery; $3 *$ : branch to the deep palmar arterial arch; 2DMA: second dorsal metacarpal artery; arrow: distance between the origin of the dorsal arterial arch and the point of ramification of the radial artery.

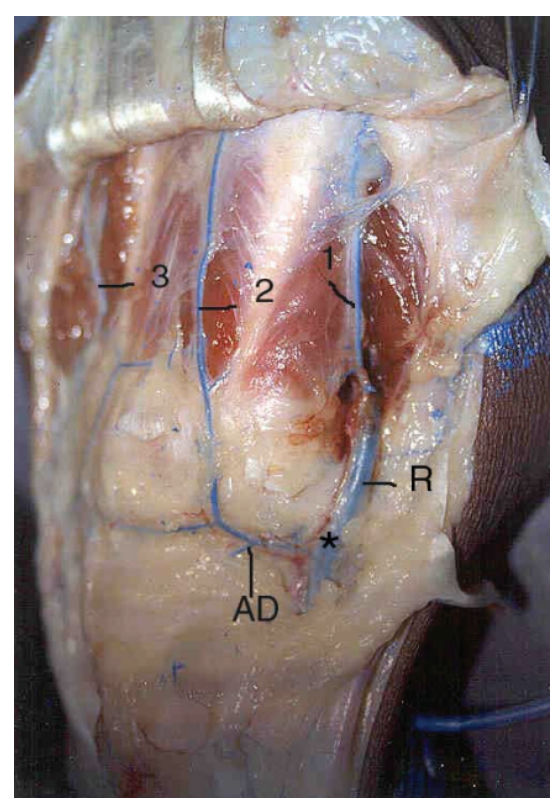

Figure 2 - Picture illustrating the typical arterial pattern observed during the dissections. 1: 1DMA; 2: 2DMA; 3: 3DMA; R: radial artery; $\mathrm{AD}$ : dorsal arterial arch. 
branches, the last one running to the dorso-ulnar aspect of the thumb.

The dorsal arterial arch (DAA) was found at the level of the distal carpal row, underneath the third and the fourth dorsal extensor compartments, and it was present in all specimens. The distance between the origin of

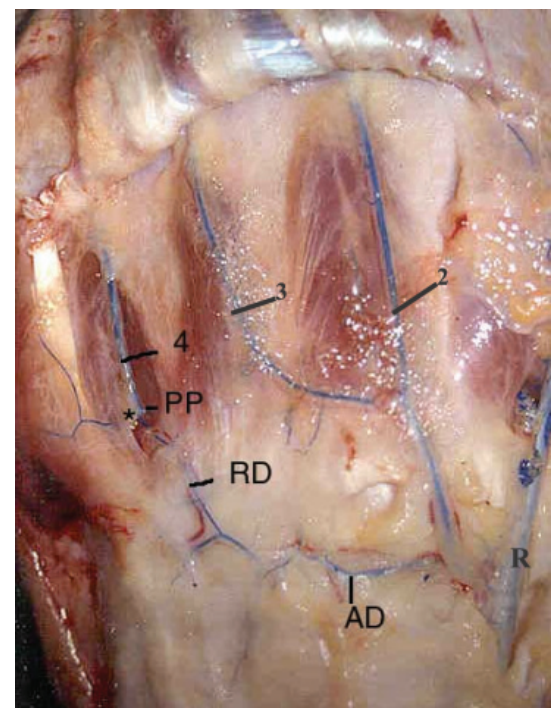

Figure 3 - Fourth DMA arising from the dorsal arterial arch and the proximal palmar communicating branch. Third DMA arising from the 2DMA. 2: 2DMA; 3: 3DMA; 4: 4DMA; PP: proximal palmar communicating branch ; RD: branch from the dorsal arterial arch; AD: dorsal arterial arch ; R: radial artery.
DAA and the distal division of the radial artery was an average of $2.0 \mathrm{~cm}$ (range 1.3 to $2.3 \mathrm{~cm}$ ) (Fig. 3). The DAA arose from the radial artery in 21 (79.8\%) cadavers (Fig. 4). In the remaining $5(19.2 \%)$, it arose from a branch of the radial artery that formed the second DMA and a communicating branch to the palmar system.

The most frequent arterial pattern observed during the dissections was the first DMA (1DMA) arising from the radial artery and the remaining DMAs arising from the DAA (Fig. 2).

The second dorsal metacarpal artery (2DMA) was present in all specimens, at the second intermetacarpal space (Fig. 2). It arose from the DAA in 18 specimens $(69.2 \%)$ and from the radial artery in $6(23.1 \%)$. In one specimen it arose directly from the first DMA, and in another one it was formed exclusively by a branch of the palmar arterial arch (PAA). In 25 (96.2\%) cadavers a proximal communicating branch arising from the palmar arch contributed to form the 2DMA. The DAA was dominant in its formation in $28 \%$ of specimens while the PAA was dominant in $8 \%$.

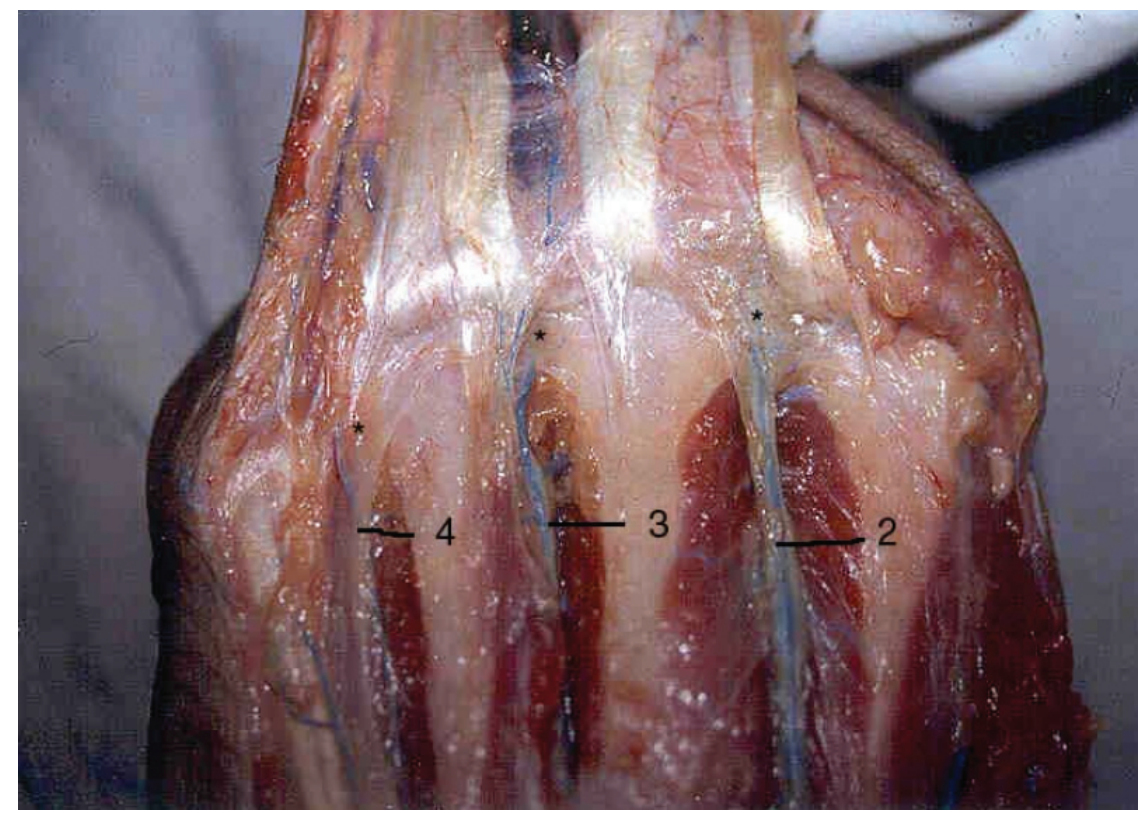

Figure 4 - Picture showing the distal cutaneous branches arising from the DMAs. The extensor tendons were cut and retracted distally. 2: 2DMA; 3: 3DMA; 4: 4DMA
The third dorsal metacarpal artery (3DMA) arose from the DAA and received a contribution from a proximal palmar arterial branch (PPAB) in 24 (92.3\%) specimens (Fig. 2). In 1 specimen it arose from the 2DMA (Fig. 4). It was found in the third intermetacarpal space in all but $1(3.8 \%)$ specimen. The PAA was dominant in $27 \%$ of the specimens.

The fourth dorsal metacarpal artery (4DMA) was formed by the DAA and the PPAB in $22(80.7 \%)$ specimens (Fig .4). In $2(7.7 \%)$ specimens it was formed exclusively by the PPAB, and in $1(3.8 \%)$ it was formed solely by the DAA. It was not found in the fourth intermetacarpal space in 2 specimens. The PAA was dominant in $38.4 \%$ of cases.

The second, third, and fourth DMAs divided into 2 branches at the level of the metacarpal heads after they had given off the distal cutaneous branches: one branch was the extension of DMA in the dorsal aspect of proximal phalange and the other was the distal palmar communicating branch (Fig. 5).

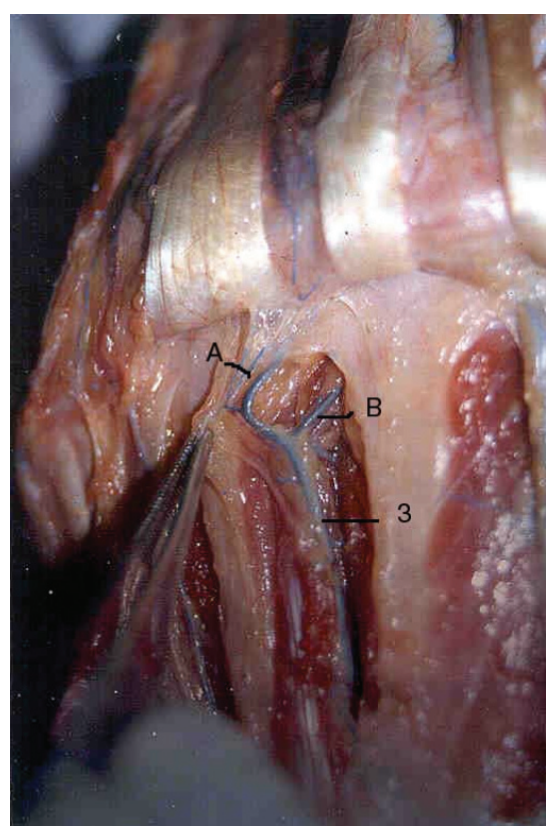

Figure 5 - Picture showing the division of the DMA into 2 branches at the level of the metacarpal head. A: branch to the dorsum of the proximal phalange; B: Distal palmar communicating branch; 3: 3DMA 


\section{CONCLUSION}

The literature regarding the arterial anatomy of the dorsal aspect of the hand was reviewed and some divergences concerning the presence and the constancy of DMAs and their relationships with the palmar arterial system were observed ${ }^{9,17-22}$.

According to previous studies ${ }^{26,27}$, the radial artery divides into 3 branches at the level of the anatomic snuffbox: the princeps pollicis artery, the 1DMA, and the branch to the deep palmar arch. This division pattern was confirmed in $84.6 \%$ of our cases, but in $15.3 \%$ of cases, a fourth branch running to the dorso-ulnar aspect of the thumb was observed.

The dissection of the DAA was very difficult due to its close relationship to the local capsuloligamentar structures and the presence of the extensor digitorum tendons.

Youssif' ${ }^{28}$ description of the 1DMA arising from the dorsal and palmar arterial arches was not confirmed by us nor by other authors ${ }^{15,17,20,25,29,30}$. Hamdy ${ }^{20}$ observed the division of 1DMA into 3 branches. In contrast, our study showed the 1DMA as a single artery or in a bifurcation pattern. Based on the variations of its course and branching pattern, we strongly suggest that to be certain to include the 1DMA, the fasciocutaneous pedicled flap based on the 1DMA must be raised in the subfascial plane, including a strip of the interosseous muscle fascia with the pedicle.

The first and second DMAs were anatomically constant, making them very safe as a source of pedicle flaps. In the other hand, the third and fourth DMAs were not found in $3.8 \%$ and $7.7 \%$ of cases, respectively. Therefore, it would be wiser to confirm their presence with Doppler or even arteriography prior to surgery. We found the third and fourth DMAs with a higher frequency than has been reported in the literature. Perhaps this finding could be explained by the different dye solution used by us; or by the different amount of significance given to smaller vessels.

Coleman ${ }^{14}$, Yousif ${ }^{28}$, and Olave ${ }^{15}$ emphasized the great importance of the palmar arterial system throughout its communicating branches in the formation of the DMAs. Our findings were more objective than those because we took into account the vessel caliber in the evaluation of the dominance of the arterial system. The PAA was dominant in the third and fourth DMAs. In the
2DMA, the DAA was dominant in the majority of cases, although a proximal palmar communicating branch was present in the majority of cases.

The characteristics of the dye solution used in this study-good penetrance, low viscosity, and quick solidification-allowed us to perform precise dissection of even very small vessels. Arteriography or contrast-enhanced magnetic resonance could be employed as alternative methods for the study of the arterial anatomy of the hand of living humans. However, the arteriography would not give a tridimensional view of the vessels, and both exams would not be able to visualize very small vessels with the precision possible in the dissections of cadavers

A very important aspect of this study was the identification and precise location of the distal cutaneous branches in all DMAs. Their constant anatomy allows us to plan the reversed flow dorsal metacarpal artery flap with greater accuracy and safety, since they represent its pivoting point. Therefore, we conclude that the flaps described by Quaba ${ }^{12}$ can be safely employed after the presence of the corresponding DMA is confirmed.

\section{RESUMO}

REZENDE MR de e col. - Estudo anatômico do sistema arterial dorsal da mão. Rev. Hosp. Clín. Fac. Med. S. Paulo 59(2):71-76, 2004.

Historicamente o sistema arterial dorsal da mão recebeu menos atenção em relação ao palmar. Os trabalhos que abordam a anatomia arterial dorsal apresentam pontos divergentes no que se refere a origem, a frequiência e a presença de ramos das artérias metacarpais dorsais. Este conhecimento se aplica, em especial, no planejamento cirúrgi- co de retalhos que tenham como área doadora o dorso da mão. O objetivo deste trabalho é o de estudar a anatomia do sistema arterial dorsal da mão, confrontando estes achados com os da literatura e desta maneira, definir parâmetros para o planejamento dos retalhos supridos pelas artérias metacarpais dorsais da mão.

CASUÍSTICA E MÉTODO: Foram realizadas 26 dissecções na região dorsal da mão direita de 26 cadáveres, através de uma incisão em forma de U de base distal. Após a cateterização da artéria radial a nível do punho, foi injetado um corante plástico de baixa viscosidade e rápida solidificação que permitiu adequada visibilização até mesmo de pequenos vasos. A artéria radial e seus ramos, o arco dorsal, as artérias metacarpais dorsais, os ramos comunicantes distais e proximais do sistema palmar e os ramos cutâneos distais, foram cuidadosamente dissecados e identificados.

RESULTADOS: Os ramos cutâneos distais provenientes das artérias metacarpais dorsais foram observados em to- 
dos os casos, em média, a 1,2 cm proximal a articulação metacarpofalangeana. A primeira artéria metacarpal dorsal apresentou três padrões diferentes em relação ao seu trajeto no primeiro espaço intermetacarpal: fascial, subfascial e misto. O padrão de ramificação da artéria radial, no primeiro espaço intermetacarpal, foi o de sua divisão em três ramos. Observamos a presença do arco arterial dorsal em 100\% dos casos, com sua origem na artéria ra- dial. A distância entre a emergência do arco dorsal e o ponto de ramificação da artéria radial foi em média de $2 \mathrm{~cm}$. As artérias primeira e segunda metacarpais dorsais estiveram presentes em todos os casos. As artérias terceira e quarta metacarpais dorsais estiveram presentes em $96,2 \%$ e $92,3 \%$ dos casos, respectivamente. Constatamos que houve uma comunicação proximal e distal do arco dorsal com o sistema palmar, através de ramos comunicantes que contribuíram para a formação das artérias metacarpais dorsais.

CONCLUSÃO: Existe uma rica rede arterial no dorso da mão, que apresenta um grande número de anastomoses com o sistema arterial palmar, permitindo a utilização desta região como uma fonte potencial de retalhos cutâneos.

UNITERMOS: Sistema arterial. Dorsal. Mão. Anatomia. Retalhos fasciocutâneos.

\section{REFERENCES}

1. Sapp J, Allen RJ, Dupin C. A reversed digital artery island flap for the treatment of fingertip injuries. J Hand Surg (Am) 1983; 18:528.

2. Smith PJ. A sliding flap to cover dorsal skin defects over the proximal interphalangeal joint. Hand 1982; 14: 271.

3. Vilain R, Dupuis JFE. Use of the flag flap for coverage of a small area on a finger or the palm. 20 years experience. Plastic Reconstr Surg 1973; 51(4): 397-401.

4. Foucher GD, Braun JB. A new island flap transfer from the dorsum of the index to the thumb. Plastic Reconstr Surg 1979; 63(3): 344-349.

5. Levame JH, Otero C, Berdugo G. Vascularization artérielle des tégumenets de la face dorsale de la main et des doigts. Ann Chir Plast 1967; 12:316-24.

6. Murakami T, Takaya K, Outi H. The origin, course and distribution of arteries to the thumb, with special reference to the so-called a. princeps pollicis. Okajimas Fol Anat Jap 1969; 46:123-137.

7. Ikeda A, Ugawa A, Kazihara Y, et al. Arterial patterns in the hand based on a three-dimensional analysis of 220 cadaver hands. J Hand Surg 1988; 13(A):501-9.

8. Rezende MR, Mattar RJ, Azze RJ, et al. Estudo clínico do retalho das artérias metacárpicas dorsais. Rev Bras Ortop 1997; $31: 231-236$

9. MARUYAMA Y - The reverse dorsal metacarpal flap. Br J Plast Surg 1990; 43:24 - 27.

10. Karacalar SA, Akin S, Özcan M. The second dorsal metacarpal flap with pivot points. Br J Plast Surg 1996; 49:97-102.

11. Pelissier P, Casoli V, Bakahach J, et al. Reverse dorsal digital and metacarpal flaps. A review of 27 cases. Plast Recontr Surg $1999 ; .103: 159-165$

12. Quaba AA, Davison PM. The distally-based dorsal hand flap. $\mathrm{Br}$ J Plast Surg 1990; 43:28-39.
13. Earley MJ. The arterial supply of the thumb, first web and index finger and its surgical application. J Hand Surg 1969; 11B(2): $163-174$.

14. Coleman SS, Anson BJ. Arterial patterns in the hand based upon a study of 650 specimens. Surg Gynecol Obstet 1961; 113(4):409-424.

15. Olave E, Prates JC, Grabrielle C, et al. Perforating branches: Important contribution to the formation of the dorsal metacarpal arteries. Scand J Plast Recontr Hand Surg 1997; $32: 221-7$.

16. Rees MJW, Taylor I. A simplified oxide cadaver injection technique. Plastic Reconstr Surg 1985, 77:141-5.

17. Dautel G, Merle M, Borreily J, et al. Variations anatorniques du réseau vasculaire de Ia prernière cominissure dorsale. Applications larribeau cerf-volant. Ann Chir Main 1989; 8:5359.

18. Earley MJ. The arterial supply of the thumb, first web and index finger and its surgical application. Br J Hand Surg 1986; $11: 163-172$

19. Earley MJ, Milner RH. Dorsal metacarpal flaps. Br J Plast Surg 1987; 40:333-341.

20. Hamdy A, El-Khatib HA. Clinical experiences with the extended first dorsal metacarpal artery island flap for thumb reconstruction. J Hand Surg (Am) 1998; 23:647.

21. Pierer G, Steffen J, Hoflemer H. The vascular blood supply of the second metacarpal bone: anatomic basis for a new vascularized bone graft in hand surgery. Surg Radiolog Anat 1992; 14:103112.

22. Khan K, Riaz M, Small JO. The use of the second dorsal metacarpal artery for vascularized bone graft. J Hand Surg 1995; 23(B):308 -310.

23. Germann C, Rutschle S, Knaia N, et al. The reverse pedicle heterodigital cross-finger island flap. J Hand Surg (Br) 1997; 22:22-25. 
24. Joshi BB. A local dorsolateral island flap for restorations of sensation after avulsion injury of fingertip pulp. Plast Reconstr Surg $1974 ; 54: 175$.

25. Sherif MM. First dorsal metacarpal artery flap in hand reconstruction. Anatomical study. J Hand Surg [Am] 1994; 19:32-8.

26. Gray DJ. Some variations appearing in the dissecting room. Stanford M BuII 1945, 3:120-127.

27. Iselin F. The flag flap. Plast Reconstr Surg 1973; 52:374-7.
28. Yousif JN, Ye Z, Sanger JR, et al. The versatile metacarpal and reverse metacarpal artery flaps in hand surgery. Ann Plast Surg 1992; 29:523-31.

29. Bertelli JA, Paglieri A, Lasssau JP. Role of the first dorsal metacarpal artery in the construction of pedicled bone graft. Surg Radiol Anat $1992 ; 14: 275-77$.

30. Lai CS, Lin SD, Chou CK, et al. A versatile method for reconstruction of finger defects: Reverse digital artery flap. $\mathrm{Br}$ J Plast Surg 1997; 45:443. 